\title{
THE FAUNA PRESERVATION SOCIETY
}

1955 LECTURE TOUR AND WILD LIFE FILM

by

MERVYN COWIE

Director, The Royal National Parks of Kenya

29th October. The Royal Festival Hall, London.

Ist November. Glasgow, McLellan Galleries.

2nd November. Edinburgh, Usher Hall.

3rd November. Dundee. Caird Hall.

4th November. Aberdeen. Y.M.C.A. Hall.

8th November, Birmingham. City Museum and Art Gallery.

9th November. Newcastle. City Hall.

10th November. Bristol. University Lecture Theatre.

14th November. Bridgwater. The Town Hall.

15th November. Norwich. Stuart Hall.

17th November. Cardiff. Reardon Smith Lecture Theatre.

Other places are being considered.

This is a preliminary notice only. In September full particulars will be sent to all members for whom the Society has addresses in the British Isles. Will members abroad who would like particulars please notify the Secretary.

\section{SOUTH AFRICAN ORNITHOLOGICAL CONGRESS}

The South African Ornithological Socicty intends to organize a Pan-African Ornithological Congress at the Victoria Falls in July, 1057. Those interested in receiving further information are asked to send their names to the Honorary Secretary, South African Ornithological Socicty, P.O. Box 1616, Capetown, South Africa, 